\title{
MARROW IRON EXAMINATION IN THE DIAGNOSIS OF IRON DEFICIENCY IN RHEUMATOID ARTHRITIS*
}

\author{
BY \\ P. C. MCCREA \\ Harrogate and District General Hospital, Harrogate
}

A moderate degree of anaemia is commonly present in patients with rheumatoid arthritis. The anaemia is usually normocytic and hypochromic and the degree of anaemia roughly parallels the activity of the disease (Nilsson, 1948; Jeffrey, 1953a). Among the varied features described in anaemia associated with arthritis are alterations in plasma volume causing anaemia through hydraemia (Robinson, 1943; Dixon, Ramcharan, and Ropes, 1955), an increased rate of red cell destruction (Mollison and Paterson, 1949; Bunim, 1954; Freireich, Ross, Bayles, Emerson, and Finch, 1954; Alexander, Richmond, Roy, and Duthie, 1956), and abnormalities in iron and porphyrin metabolism (Jeffrey, 1953b).

The effect of iron therapy on anaemia in this disease has been studied by several workers. Sinclair and Duthie (1950) reported that haemoglobin levels improved with intravenous iron therapy in cases in which oral iron had proved ineffective. Ross (1950) and Jeffrey (1953a) also reported good results with intravenous iron in this condition but all these workers found numerous cases which failed to respond to this treatment. Jeffrey (1953b), in a search for prognostic factors which might indicate whether the anaemia in any given case was likely to respond to intravenous iron, was unable to derive any material help from assessment of many clinical and laboratory features of the disease. Another group of workers (Kuhns, Gubler, Cartwright, and Wintrobe, 1950) stated that the anaemia and hypoferraemia of rheumatoid arthritis were not appreciably influenced by intravenous iron.

Reports on the value of intravenous iron in the treatment of this anaemia are conflicting and the indications for its use are not clear. In view of the possible dangers of this type of therapy, especially in patients who are not iron-deficient (Dameshek, 1950; Holly, 1951), it is desirable that intravenous iron should not be used except in cases of iron-

\footnotetext{
* Based on part of a thesis for the degree of M.D. in the Queen's University of Belfast.
}

deficiency anaemia. The first steps in the diagnosis of iron deficiency anaemia are examination of peripheral blood smears and calculation of "absolute values": the mean cell volume (M.C.V.) and the mean cell haemoglobin concentration (M.C.H.C.). In iron-deficiency anaemia of long standing, the red cells are hypochromic and microcytic and there is decrease in the M.C.V. and M.C.H.C. Certain conditions, e.g. thalassaemia and the anaemia of chronic infection in which the red cells may be hypochromic, may be confused with chronic iron deficiency from peripheral blood examination alone. In true iron deficiency, however, more specific diagnostic findings are present: the absence of iron from the bone marrow, the absence of iron granules in the normoblasts, and a low serum iron level (Coleman, Stevens, and Finch, 1955). Coleman and his colleagues state that, in their experience, the most reliable and sensitive diagnostic test for irondeficiency is the absence of iron from the marrow.

Bone marrow examination for iron as a means of assessing body iron stores has been recommended by many workers (Rath and Finch, 1948; Hutchison, 1953; Stevens, Coleman, and Finch, 1953). Although it is not certain that marrow iron is a fair reflection of total iron storage, reports from workers who have investigated iron storage in the liver or spleen concurrently with marrow examination indicate that iron storage in each case was comparable for the various sites at the time (Pratt and Johnson, 1954; Beutler, Drennan, and Block, 1954). It is generally agreed that iron deficiency alone of the conditions studied is characterized by absence of marrow iron (Hutchison, 1953; Stevens and others, 1953). Hutchison (1953) states that the hypochromic anaemia due to iron deficiency can be differentiated from that due to chronic infection or intoxication, by examination of marrow iron. In the former condition there is absence of marrow iron whereas in the latter a varying amount of iron can be demonstrated.

In the work here reported, marrow iron examinations were used to study iron deficiency in cases of rheumatoid arthritis and the effect of intravenous 
iron on the anaemia in these cases was recorded. The cytology of the bone marrow was also studied, particular attention being paid to the maturation of the erythroid series and to the relation between marrow plasma cell levels and serum globulin concentrations.

\section{Materials and Methods}

33 cases, all in-patients, suffering from active rheumatoid arthritis were investigated. Each case was classified as suffering from "slightly active" (+), "moderately active" $(++)$, or "very active" $(+++)$ disease. In classification, the degree of joint pain and tenderness, the presence of general constitutional disturbance, and the erythrocyte sedimentation rate (E.S.R.) were considered. In each case the initial haemoglobin level was $11 \mathrm{~g}$. per $100 \mathrm{ml}$. or less, the mean corpuscular haemoglobin concentration (M.C.H.C.) was 29 per cent. or less, and the mean cell volume (M.C.V.) was within normal limits or diminished. Two rheumatoid patients had previously suffered blood loss from haemorrhoids, but were not bleeding at the time of this investigation. Two control cases with uncomplicated iron deficiency anaemia due to blood loss were also investigated. One had suffered from repeated epistaxis for some months, and the other was anaemic because of menorrhagia.

Bone marrow examination was carried out in each case before the start of iron therapy. Approximately $1 \mathrm{~g}$. of an iron preparation for intravenous use (saccharated oxide of iron in colloidal solution, either "Iviron" or "Ferrivenin", containing $20 \mathrm{mg}$. colloidal iron per ml.) was administered in from six to ten injections during a period of 8 to 14 days. As iron was given intravenously, the question of absorption from the gastro-intestinal tract did not arise. Reticulocyte counts were made on at least two occasions between the 5th and 12th days after the start of iron therapy. The results of treatment were assessed at the end of a test period of 4 to 5 weeks. In eight cases observations were continued at the end of the initial trial period, so that, in some cases, the progress of the anaemia was studied for periods of up to 3 months from starting treatment with iron.

Bone Marrow Examination.-Marrow puncture was performed in the manubrium or first or second pieces of the body of the sternum under local anaesthesia. Smears were made from the first few drops of marrow aspirated, after which a further quantity $(0.5$ to $1 \mathrm{ml}$.) of a mixture of blood and marrow was withdrawn into fixative. Histological sections were prepared from aspirated marrow and were stained for iron by the Prussian blue method, using a modification (Hutchison, 1953) of the technique of Cappell, Hutchison, and Smith (1947). Storage iron is present in the bone marrow in two forms: ferritin and haemosiderin (Pirrie, 1950). It is generally believed that only haemosiderin is stained by the Prussian blue method, but Finch, Hegsted, Kinney, Thomas, and four others (1950) stated that large amounts of ferritin in a cell might give a positive reaction. The material giving a positive Prussian blue reaction may not be a single chemical entity, and the term "stainable iron" is often used in preference to haemosiderin (Hutchison, 1953).

Examination of Marrow Sections.-In marrow sections stained by the Prussian blue method, iron is seen in the reticuloendothelial cells giving a diffuse blue colour to the cell or in the form of intracellular granules or as dense clumps. The distribution of iron throughout the marrow is irregular and several fragments are required for examination particularly in order to support a negative finding (Hutchison, 1953).

A rough classification of the marrows with regard to iron content was made:

(1) Devoid of stainable iron.

(2) Containing a "small" amount of iron; a few cells showed a diffuse blue coloration and/or more densely staining granules.

(3) Containing a "moderate" amount of iron; e.g. a larger number of cells showed blue staining of the cytoplasm with numerous granules and perhaps small clumps.

(4) Containing a "large" amount of iron; densely staining clumps were present.

Where small amounts of iron were present, the result was confirmed by staining a further section. Negative findings were checked by staining a further section in parallel with a section known to be positive for iron.

Examination of Marrow Smears.-500 nucleated cells were counted and the myeloid:erythroid ratio was determined. In each case, the percentages of the different types of erythroblasts in a count of 100 nucleateos. erythroid cells were estimated. Many factors (e.g. the wide variation in the normal range of differential counts, the irregular distribution of marrow cells on smears, and dilution with peripheral blood) make minor alterations in marrow cytology difficult to establish (Dacie, 1950a). Erythroid maturation was studied here by expressing the numbers of different classes of erythroblasts as percentages of the total erythroblast count, rather than as percentages of the total nucleated cells present. In the absence of marked peripheral erythroblastaemia, the factor of dilution with peripheral blood does not affect the accuracy of these differential erythroblast counts (Dacie and White, 1949).

Other Tests.-Haemoglobin was estimated on samples of venous blood as alkaline haematin in a photoelectric colorimeter, using the artificial standard of Gibson and Harrison (1945). Reticulocytes were counted by the method of Dacie (1950b). Serum protein levels were determined by the Biuret method. Erythrocyte sedimentation rates were measured by Westergren's method.

\section{Results}

A significant response to iron therapy has to be evaluated in the light of physiological fluctuations and errors in haemoglobin measurement (Coleman and others, 1955). Coleman and his colleagues defined a "significant response" as an increase in 
TABLE I

RESULTS OF MARROW IRON EXAMINATION AND INTRAVENOUS IRON THERAPY

\begin{tabular}{|c|c|c|c|c|c|c|c|c|c|}
\hline $\begin{array}{c}\text { Case } \\
\text { No. }\end{array}$ & Sex & $\begin{array}{c}\text { Age } \\
\text { (yrs) }\end{array}$ & $\begin{array}{c}\text { Degree of } \\
\text { Disease } \\
\text { Activity }\end{array}$ & $\begin{array}{c}\text { Initial } \\
\text { Haemo- } \\
\text { globin } \\
\text { Level } \\
\text { (g./100 ml.) }\end{array}$ & $\begin{array}{l}\text { M.C.H.C. } \\
\text { (per cent.) }\end{array}$ & $\begin{array}{c}\text { Haemo- } \\
\text { globin } \\
\text { after Iron } \\
\text { Therapy } \\
\text { (g./100 ml.) }\end{array}$ & $\begin{array}{c}\text { Increase in } \\
\text { Haemo- } \\
\text { globin } \\
\text { (g. } / 100 \mathrm{ml} .)\end{array}$ & $\begin{array}{l}\text { Marrow Iron } \\
\text { (amount) }\end{array}$ & $\begin{array}{l}\text { Test } \\
\text { Period } \\
\text { (days) }\end{array}$ \\
\hline $\begin{array}{r}1 \\
2 \\
3 \\
4 \\
5 \\
6 \\
7 \\
8 \\
9 \\
10 \\
11 \\
12 \\
13 \\
14 \\
15 \\
16 \\
17 \\
18 \\
19 \\
20 \\
21 \\
22 \\
23 \\
24 \\
25 \\
26 \\
27 \\
28 \\
29 \\
30 \\
31 \\
32 \\
33\end{array}$ & $\begin{array}{l}\mathbf{F} \\
\mathbf{M} \\
\mathbf{M} \\
\mathbf{F} \\
\mathbf{F} \\
\mathbf{M} \\
\mathbf{M} \\
\mathbf{F} \\
\mathbf{M} \\
\mathbf{F} \\
\mathbf{F} \\
\mathbf{M} \\
\mathbf{F} \\
\mathbf{F} \\
\mathbf{F} \\
\mathbf{F} \\
\mathbf{F} \\
\mathbf{F} \\
\mathbf{F} \\
\mathbf{F} \\
\mathbf{F} \\
\mathbf{F} \\
\mathbf{F} \\
\mathbf{M} \\
\mathbf{F} \\
\mathbf{M} \\
\mathbf{M} \\
\mathbf{F} \\
\mathbf{F} \\
\mathbf{M} \\
\mathbf{F} \\
\mathbf{F} \\
\mathbf{F}\end{array}$ & $\begin{array}{l}52 \\
24 \\
43 \\
33 \\
59 \\
56 \\
67 \\
60 \\
49 \\
50 \\
68 \\
66 \\
55 \\
39 \\
46 \\
63 \\
49 \\
61 \\
60 \\
70 \\
29 \\
65 \\
44 \\
57 \\
56 \\
45 \\
62 \\
56 \\
58 \\
56 \\
58 \\
55 \\
54\end{array}$ & 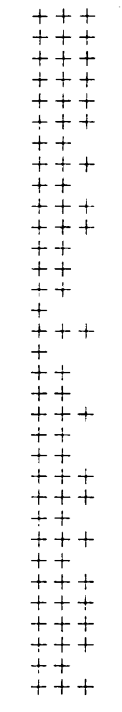 & 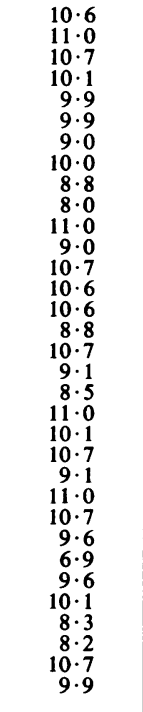 & $\begin{array}{l}29 \\
28 \\
29 \\
28 \\
28 \\
28 \\
25 \\
29 \\
26 \\
26 \\
29 \\
28 \\
29 \\
29 \\
28 \\
27 \\
27 \\
27 \\
28 \\
29 \\
29 \\
29 \\
28 \\
28 \\
29 \\
29 \\
26 \\
28 \\
28 \\
26 \\
27 \\
29 \\
28\end{array}$ & 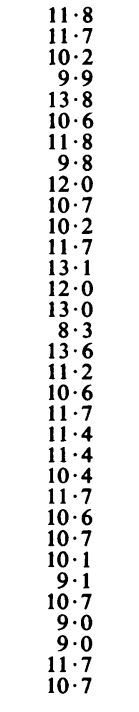 & 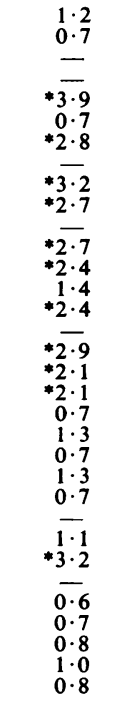 & $\begin{array}{l}\text { Large } \\
\text { Moderate } \\
\text { Large } \\
\text { Moderate } \\
\text { Moderate } \\
\text { Large } \\
\text { None } \\
\text { Moderate } \\
\text { None } \\
\text { None } \\
\text { Large } \\
\text { None } \\
\text { None } \\
\text { None } \\
\text { None } \\
\text { Moderate } \\
\text { None } \\
\text { None } \\
\text { None } \\
\text { Moderate } \\
\text { Small } \\
\text { Small } \\
\text { Moderate } \\
\text { Small } \\
\text { Moderate } \\
\text { Large } \\
\text { None } \\
\text { Large } \\
\text { Moderate } \\
\text { Large } \\
\text { Small } \\
\text { Moderate } \\
\text { Moderate }\end{array}$ & $\begin{array}{l}29 \\
35 \\
30 \\
31 \\
35 \\
28 \\
28 \\
32 \\
35 \\
31 \\
28 \\
32 \\
26 \\
28 \\
28 \\
35 \\
28 \\
28 \\
28 \\
30 \\
28 \\
29 \\
30 \\
30 \\
28 \\
35 \\
28 \\
30 \\
29 \\
29 \\
35 \\
35 \\
31\end{array}$ \\
\hline
\end{tabular}

* Rise in haemoglobin of $2 \mathrm{~g} . / 100 \mathrm{ml}$. or more.

TABLE II

RESULTS OF INTRAVENOUS IRON THERAPY IN TWO CONTROL CASES

\begin{tabular}{|c|c|c|c|c|c|c|c|}
\hline Clinical Diagnosis & Sex & $\begin{array}{l}\text { Age } \\
\text { (yrs) }\end{array}$ & $\begin{array}{c}\text { Initial } \\
\text { Haemoglobin } \\
(\mathbf{g} . / 100 \mathrm{ml} .)\end{array}$ & $\begin{array}{l}\text { M.C.H.C. } \\
\text { (per cent.) }\end{array}$ & $\begin{array}{l}\text { Haemoglobin } \\
\text { after } \\
\text { Iron Therapy } \\
\text { (g. } / 100 \mathrm{ml} .)\end{array}$ & $\begin{array}{l}\text { Increase in } \\
\text { Haemoglobin } \\
\text { (g./100 ml.) }\end{array}$ & $\begin{array}{c}\text { Trial Period } \\
\text { (days) }\end{array}$ \\
\hline Epistaxis & $\mathbf{M}$ & 58 & $6 \cdot 4$ & 25 & $12 \cdot 3$ & $5 \cdot 9$ & 28 \\
\hline Menorrhagia & $\mathbf{F}$ & 44 & $9 \cdot 0$ & 26 & $13 \cdot 4$ & $4 \cdot 4$ & 30 \\
\hline
\end{tabular}

haemoglobin of $2 \mathrm{~g}$. per $100 \mathrm{ml}$. or more. In assessing the results of the present investigation this same arbitrary response level has been used.

The results are given in Table I. In eleven cases no stainable marrow iron was present. In ten of these eleven cases the haemoglobin level rose by more than $2 \mathrm{~g}$. per $100 \mathrm{ml}$. In one patient (Case 14) the rise in haemoglobin was only $1.4 \mathrm{~g}$. per $100 \mathrm{ml}$. With one exception (Case 10), the patients in this group suffered from only moderately or slightly active disease. The average rise in haemoglobin in the ten cases was less than that seen in the control cases who suffered from uncomplicated iron deficiency anaemia (Table II). The reticulocyte counts in the arthritic patients were low in comparison with those observed in the control cases (Table III).
TABle III

MAXIMUM RETICULOCYTE COUNTS IN PATIENTS WHO RESPONDED TO IRON THERAPY

(Ten Patients with absent marrow iron and two control patients)

\begin{tabular}{|c|c|c|c|c|c|}
\hline Group & Case No. & Sex & $\begin{array}{l}\text { Age } \\
\text { (yrs) }\end{array}$ & $\begin{array}{c}\text { Initial } \\
\text { Haemo- } \\
\text { globin } \\
\text { (g. } / 100 \mathrm{ml} .)\end{array}$ & $\begin{array}{l}\text { Maximum } \\
\text { Reticulocyte } \\
\text { Response } \\
\text { (per cent.) }\end{array}$ \\
\hline Control & $\begin{array}{l}\text { Epistaxis } \\
\text { Menorrhagia }\end{array}$ & $\begin{array}{l}\mathbf{M} \\
\mathbf{F}\end{array}$ & $\begin{array}{l}58 \\
44\end{array}$ & $\begin{array}{l}6 \cdot 4 \\
9 \cdot 0\end{array}$ & $\begin{array}{r}11 \cdot 5 \\
5 \cdot 4\end{array}$ \\
\hline $\begin{array}{l}\text { Marrow } \\
\text { Iron } \\
\text { Absent }\end{array}$ & $\begin{array}{r}7 \\
9 \\
10 \\
12 \\
13 \\
15 \\
17 \\
18 \\
19 \\
27\end{array}$ & $\begin{array}{l}\mathbf{M} \\
\mathbf{M} \\
\mathbf{F} \\
\mathbf{M} \\
\mathbf{F} \\
\mathbf{F} \\
\mathbf{F} \\
\mathbf{F} \\
\mathbf{F} \\
\mathbf{M}\end{array}$ & $\begin{array}{l}67 \\
49 \\
50 \\
66 \\
55 \\
46 \\
49 \\
61 \\
60 \\
62\end{array}$ & $\begin{array}{r}9 \cdot 0 \\
8.8 \\
8.0 \\
9.0 \\
10.7 \\
10.6 \\
10.7 \\
9.1 \\
8.5 \\
6.9\end{array}$ & $\begin{array}{l}2 \cdot 2 \\
4 \cdot 2 \\
2 \cdot 3 \\
2 \cdot 5 \\
3 \cdot 5 \\
2 \cdot 5 \\
1 \cdot 5 \\
1 \cdot 3 \\
3 \cdot 5 \\
5 \cdot 5\end{array}$ \\
\hline
\end{tabular}


In 22 cases a varying amount of marrow iron was demonstrated. The haemoglobin level rose by $2 \mathrm{~g}$. per $100 \mathrm{ml}$. or more in only one patient (Case 5). This patient had improved clinically and there was a marked fall in the erythrocyte sedimentation rate during the trial period.

Ten of eleven cases $(91$ per cent. in which the marrow was devoid of iron responded to iron by a rise in haemoglobin of more than $2 \mathrm{~g}$. per $100 \mathrm{ml}$. Only one of the 22 cases ( 5 per cent. in which iron was demonstrated showed a response. Although computed on a small number of cases, the difference in the two response rates (91 as against 5 per cent.) could not have arisen by chance.
The results of follow-up studies in eight cases which were refractory to iron therapy in the initial trial period are given in Table IV. No appreciable rise in haemoglobin occurred in any case over the longer period of observation.

Marrow Cytology.-A summary of the findings is given in Table V. There is no marked hyperplasia of the erythroid series, only seven cases showing myeloid:erythroid ratios of 2:1 or less. Examination of marrow sections confirmed that there were no gross hyperplasia. In most cases, the numbers of basophilic normoblasts were increased when the figures were compared with those given for fifteen

TABLE IV

RESULTS OF FOLLOW-UP STUDIES IN IRON-REFRACTORY CASES

\begin{tabular}{|c|c|c|c|c|c|c|c|}
\hline \multirow[b]{2}{*}{ Case No. } & \multirow[b]{2}{*}{ Sex } & \multirow{2}{*}{$\begin{array}{l}\text { Age } \\
\text { (yrs) }\end{array}$} & \multicolumn{2}{|c|}{ Before Iron Therapy } & \multicolumn{2}{|c|}{ After Iron Therapy } & \multirow{2}{*}{$\begin{array}{r}\text { Time } \\
\text { (days) }\end{array}$} \\
\hline & & & $\begin{array}{c}\text { Haemoglobin } \\
\text { (g./100 ml.) }\end{array}$ & $\underset{(\mathrm{mm} . / \mathrm{hr})}{\text { E.S.R. }}$ & $\begin{array}{l}\text { Haemoglobin } \\
(\mathrm{g} . / 100 \mathrm{ml} .)\end{array}$ & $\underset{(\mathrm{mm} / \mathrm{hr})}{\text { E.S.R. }}$ & \\
\hline $\begin{array}{r}2 \\
3 \\
4 \\
8 \\
11 \\
16 \\
20 \\
23\end{array}$ & $\begin{array}{l}\mathbf{M} \\
\mathbf{M} \\
\mathbf{F} \\
\mathbf{F} \\
\mathbf{F} \\
\mathbf{F} \\
\mathbf{F} \\
\mathbf{F}\end{array}$ & $\begin{array}{l}24 \\
43 \\
33 \\
60 \\
68 \\
63 \\
70 \\
44\end{array}$ & $\begin{array}{r}11.0 \\
10.7 \\
10.1 \\
9.4 \\
11.0 \\
8.8 \\
11.0 \\
9.1\end{array}$ & $\begin{array}{r}68 \\
98 \\
66 \\
78 \\
66 \\
120 \\
60 \\
62\end{array}$ & $\begin{array}{r}12.5 \\
11.8 \\
9.9 \\
9.9 \\
12.0 \\
8.5 \\
11.2 \\
10.7\end{array}$ & $\begin{array}{l}52 \\
90 \\
62 \\
80 \\
48 \\
94 \\
62 \\
43\end{array}$ & $\begin{array}{l}96 \\
75 \\
97 \\
41 \\
74 \\
70 \\
97 \\
55\end{array}$ \\
\hline
\end{tabular}

TABLE V

MARROW CYTOLOGY

\begin{tabular}{|c|c|c|c|c|c|c|}
\hline Case No. & $\begin{array}{l}\text { Myeloid : Erythroid } \\
\text { Ratio }\end{array}$ & $\begin{array}{c}\text { Pro- } \\
\text { Normoblasts* }\end{array}$ & $\begin{array}{l}\text { Basophilic } \\
\text { Normoblasts* }\end{array}$ & $\begin{array}{l}\text { Polychromatic } \\
\text { Normoblasts* }\end{array}$ & $\begin{array}{c}\text { Pyknotic } \\
\text { Normoblasts* }\end{array}$ & $\begin{array}{l}\text { Plasma Cells } \\
\text { (per cent.) }\end{array}$ \\
\hline $\begin{array}{l}1 \\
2 \\
3 \\
4 \\
5 \\
6 \\
7 \\
8 \\
9 \\
10 \\
11 \\
12 \\
13 \\
14 \\
15 \\
16 \\
17 \\
18 \\
19 \\
20 \\
21 \\
22 \\
23 \\
24 \\
25 \\
26 \\
27 \\
28 \\
29 \\
30 \\
31 \\
32 \\
33\end{array}$ & 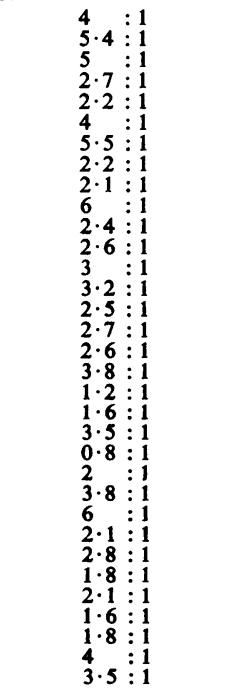 & $\begin{array}{l}1 \\
1 \\
3 \\
3 \\
2 \\
1 \\
1 \\
1 \\
3 \\
4 \\
3 \\
1 \\
1 \\
4 \\
1 \\
3 \\
2 \\
1 \\
4 \\
1 \\
1 \\
2 \\
3 \\
4 \\
1 \\
1 \\
3 \\
1 \\
2 \\
5 \\
1 \\
2\end{array}$ & $\begin{array}{r}7 \\
4 \\
12 \\
7 \\
15 \\
17 \\
5 \\
12 \\
5 \\
14 \\
19 \\
10 \\
15 \\
11 \\
18 \\
14 \\
13 \\
14 \\
6 \\
20 \\
12 \\
12 \\
10 \\
11 \\
21 \\
14 \\
7 \\
17 \\
17 \\
21 \\
37 \\
22 \\
19\end{array}$ & $\begin{array}{l}58 \\
69 \\
73 \\
68 \\
66 \\
67 \\
55 \\
69 \\
46 \\
49 \\
57 \\
61 \\
28 \\
74 \\
47 \\
69 \\
61 \\
54 \\
54 \\
54 \\
65 \\
57 \\
70 \\
51 \\
50 \\
64 \\
53 \\
60 \\
73 \\
48 \\
34 \\
58 \\
52\end{array}$ & $\begin{array}{l}34 \\
27 \\
14 \\
22 \\
16 \\
14 \\
39 \\
18 \\
48 \\
34 \\
20 \\
26 \\
56 \\
14 \\
31 \\
16 \\
23 \\
30 \\
39 \\
22 \\
22 \\
30 \\
18 \\
35 \\
25 \\
21 \\
39 \\
20 \\
9 \\
29 \\
19 \\
19 \\
27\end{array}$ & 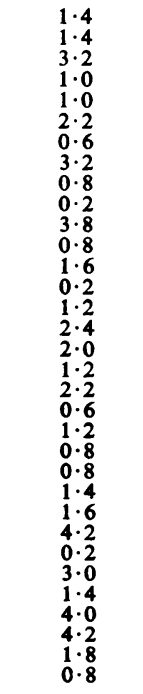 \\
\hline \multicolumn{2}{|c|}{$\begin{array}{l}\text { Normal Series of } \\
\text { Dacie and White (1949) }\end{array}$} & 2 & 5 & 51 & 42 & - \\
\hline
\end{tabular}

* Percentage per 100 nucleated erythroid cells counted. 
normal individuals by Dacie and White (1949). This increase was seen both in marrows which contained iron and in those which were devoid of iron. The basophilic normoblasts appeared to be of normal size, but in most cases some of the more mature normoblasts were smaller than normal. These micronormoblasts were seen in marrows which contained iron and in marrows in which no iron was demonstrated, but they were more plentiful in the marrows of the iron-deficient group, e.g. Cases 7, 9, and 27. The myeloid series showed no marked deviation from normal. Plasma cell levels were greater than 2 per cent. in ten of the 33 cases examined. In nine cases in which serum globulins were estimated, the results show that plasma cell levels greater than 2 per cent. were constantly associated with serum globulin concentrations of more than 3 g. per $100 \mathrm{ml}$., although hyperglobulinaemia was not invariably accompanied by marrow plasmacytosis (Table VI). In all cases megakaryocytes were plentiful, but in some they appeared to be present in relatively larger numbers.

TABLE VI

MARROW PLASMA CELLS AND SERUM GLOBULIN LEVELS

\begin{tabular}{c|c|c|c|c}
\hline Case No. & Sex & $\begin{array}{c}\text { Age } \\
\text { (yrs) }\end{array}$ & $\begin{array}{c}\text { Marrow } \\
\text { Plasma Cells } \\
\text { (per cent.) }\end{array}$ & $\begin{array}{c}\text { Serum } \\
\text { Globulin } \\
\text { (g./100 ml.) }\end{array}$ \\
\hline 3 & M & 43 & $3 \cdot 2$ & $4 \cdot 4$ \\
26 & M & 45 & $4 \cdot 2$ & $4 \cdot 2$ \\
27 & M & 62 & $0 \cdot 2$ & $2 \cdot 7$ \\
28 & F & 56 & $3 \cdot 0$ & $3 \cdot 4$ \\
29 & F & 58 & $1 \cdot 4$ & $5 \cdot 2$ \\
30 & M & 56 & $4 \cdot 0$ & $4 \cdot 0$ \\
31 & F & 58 & $4 \cdot 2$ & $3 \cdot 2$ \\
32 & F & 55 & $1 \cdot 8$ & $2 \cdot 4$ \\
33 & F & 54 & $0 \cdot 8$ & $3 \cdot 2$ \\
\hline
\end{tabular}

\section{Discussion}

In eleven of 33 patients examined, no marrow iron was demonstrated. Losses due to menstruation, pregnancy, and lactation were possible sources of iron depletion in the seven females in this group. Two of the four male patients had a history of bleeding from haemorrhoids. No explanation for the reduced iron stores in the remaining two male patients was found. Only one patient in this group failed to respond to iron therapy.

In the remaining 22 cases a varying amount of marrow iron was demonstrated. The single case in which there was a considerable rise in haemoglobin, had undergone marked clinical improvement during the period of investigation. Previous workers (Sinclair and Duthie, 1949, 1950; Ross, 1950; Jeffrey, 1953b) have reported that intravenous iron frequently improves the anaemia associated with arthritis, but Kuhns and others (1950) found that the anaemia was not appreciably influenced by large doses of iron given intravenously. Sinclair and Duthie (1950) noticed a striking fall in the erythrocyte sedimentation rate in many of their cases which responded, a finding which suggests that clinical improvement in the disease could not be excluded as the cause of the rise in haemoglobin. Ross (1950) suggested that a "lag" period existed before intravenous iron produced its maximum effect. The results of iron therapy, Ross claimed, were better after a trial period of 3 months than after one month. The results of follow-up studies in the present series do not bear out Ross's observation, no appreciable haematological improvement taking place so long as disease activity persisted (Table IV). Though the assessment of haematological improvement by peripheral blood figures alone, without reference to the total circulating haemoglobin as determined by the blood volume, may be fallacious (Whitby and Britton, 1953), the response of an anaemia to any given therapy is usually judged by the degree of reticulocytosis and by the rise in haemoglobin. Since the degree of reticulocytosis is variable, depending, for example, on the severity of the anaemia, it is usually more appropriate to determine the effectiveness of iron therapy from the rise in haemoglobin (Coleman and others, 1955). In the present study, the responses to iron therapy in the iron-deficient rheumatoid group are only moderate when compared with those observed in the control cases who suffered from uncomplicated iron deficiency. With one exception, the irondeficient rheumatoid group suffered from only moderately or slightly active disease, and, in general, the degree of anaemia present in this group was out of proportion to the severity of the disease. The higher haemoglobin levels which were found after response to iron therapy were more in keeping with those to be expected if the anaemia had been due to disease activity alone. Stevens (1956) points out that absence of marrow iron, though an indication that iron stores are reduced, does not guarantee that iron deficiency is the only cause of the anaemia. This is the possible explanation, for the poor response to iron therapy of Case 14 in which the marrow was devoid of iron. It might also explain the incomplete response to iron noticed by Jeffrey (1953b) in cases of anaemia associated with rheumatoid arthritis. In these cases, although the blood picture improved after iron therapy, the haemoglobin failed to return to normal. In one case in the present study (Case 18), after an initial response to iron therapy, the anaemia became refractory to further intravenous iron therapy at 
the higher haemoglobin level reached. It is possible that anaemia in certain cases of rheumatoid arthritis is only partially due to iron deficiency. When this iron deficiency is corrected, the residual anaemia in these cases, like the anaemia in the iron-refractory group, may be due to a toxic factor or factors associated with disease activity.

Previous reports on marrow iron stores in cases of rheumatoid arthritis indicate that some marrow iron was present in the majority. Pratt and Johnson (1954) found iron storage greater than normal in four of five anaemic rheumatoid patients. Richmond, Gardner, Roy, and Duthie (1956) examined sternal marrow samples from 61 patients with rheumatoid arthritis and anaemia. In nineteen cases no stainable iron was demonstrable. Iron was present in varying amount in the remaining 42 cases. There is evidence that all marrow iron is available for haemoglobin production. Hutchison (1953) pointed out that the absence of marrow iron in iron-deficient states was proof that all forms of stainable marrow iron could be used for haemoglobin synthesis. Finch and others (1950) concluded, from the results of phlebotomy experiments in dogs, that all intracellular iron was available for haemoglobin production should the need arise. The marrow iron stores in anaemic rheumatoid patients presumably represent iron which, though available, has not been used for haemoglobin reproduction. This does not mean, however, that the primary defect in erythropoiesis is an inability of the developing cells to utilize iron. For example, in a case of pernicious anaemia associated with rheumatoid arthritis investigated by the author, a large amount of -marrow iron was demonstrated, and after vitamin $B_{12}$ therapy the blood picture improved. In this instance the utilization of iron was impaired because of deficiency of vitamin $B_{12}$. Spontaneous improvement in the anaemia associated with rheumatoid arthritis has been described (Jeffrey, 1953a). Although the importance of alteration in plasma volume in producing a rise in haemoglobin in association with clinical remission in this disease has been stressed (Dixon and others, 1955), it seems reasonable to assume that, when spontaneous improvement does take place, marrow iron stores are utilized for haemoglobin synthesis. In patients whose iron stores are small, the possibility exists that, should clinical improvement occur, the amount of storage iron might be insufficient to restore the haemoglobin to normal. If this were the case, these patients would then require iron therapy to correct the anaemia.

In the majority of the bone marrows examined, the percentage of basophilic normoblasts was increased (Table V). A similar change in the erythroid series in cases of rheumatoid arthritis was noted by Nilsson (1948). This disturbance of maturation was present both in marrows which were devoid of iron and in those which contained iron. The work of Thorell (1947) and of Hammarsten, Thorell, Åqvist, Eliasson, and Åkerman (1953) suggests that haemoglobin synthesis starts after the basophilic normoblast stage. The experiments of Lajtha and Suit (1955), who measured the uptake of radio-iron by nucleated red cells in vitro, indicate that iron uptake is maximal in the late pronormoblast and basophilic normoblast stage. It is possible that the presence of a large percentage of basophilic normoblasts may be indicative of a state in which haemoglobin synthesis is retarded, either because iron is lacking as in iron deficiency, or because of non-utilization of iron as in states characterized by bone marrow dysfunction. This view receives support from the observations of Leitner, Britton, and Neumark (1949) that the percentage of basophilic normoblasts is increased in the bone marrow of patients with iron deficiency anaemia. Marrow plasma cell levels were slightly increased in ten of the 33 cases examined in the present study (Table V). Marrow plasmacytosis in rheumatoid arthritis has been noted by several authors (Hayhoe and Smith, 1951; Klein and Block, 1953; Richmono and others, 1956). In the series of cases examined by Richmond and others (1956), the marrow plasma cell counts were significantly related to the serum globulin level, though hyperglobulinaemia was not invariably associated with marrow plasmacytosis. The findings in the present study confirm their observations, in that hyperglobulinaemia was not constantly accompanied by marrow plasmacytosis although a raised serum globulin level was always found in cases in which an increase in marrow plasma cells was a feature (Table VI). Plasmacytosis appears to be a non-specific response, as it is found in neoplastic, granulomatous, infectious, and allergic states (Klein and Block, 1953).

The exact cause of the anaemia in rheumatoid arthritis is not known. A significant increase in plasma volume in anaemic patients with arthritis has been described (Robinson, 1943; Dixon and others, 1955) and an increased rate of red cell destruction has been demonstrated in this disease (Bunim, 1954; Freireich and others, 1954; Alexander and others, 1956). In a study of the life-span of normal red cells in the circulation of patients with rheumatoid arthritis (McCrea, 1957), six of the iron refractory group of patients were examined; five of these six patients, Cases 28-32, eliminated normal 
red cells at two to four times the normal rate. It is unlikely, however, that an increase in plasma volume and an increased rate of red cell destruction could completely account for anaemia in rheumatoid arthritis, particularly in view of the abnormalities in iron metabolism that have been described in this disease (Nilsson, 1948; Jeffrey, 1953b). In some cases in the present study, iron deficiency played a part in the production of anaemia. The factors responsible for anaemia in the patients who failed to respond to intravenous iron therapy and for the residual anaemia after incomplete response to iron are not completely understood. Though an increased rate of red cell destruction is of importance in causing anaemia in some of these cases, a further fundamental defect is the inability to produce fully haemoglobinized red cells despite the presence of unutilized iron stores. The exact nature of this defect is unknown, but in the present study it was not corrected by intravenous iron therapy.

In this work, a response to iron therapy could not have been predicted from peripheral blood examination alone, as the majority of the patients failed to respond despite the fact that the M.C.H.C. was lowered in each case. A much more reliable indication of the probable success or failure of intravenous iron therapy was afforded by marrow iron examination. Iron was given intravenously rather than orally in the present study so that the question of failure of absorption from the intestinal tract might not arise. It has been shown that absorption of oral iron in anaemic patients with rheumatoid arthritis is normal (Roy, Alexander, and Duthie, 1955). If this be so, oral iron should be as effective as parenteral iron in the treatment of iron deficiency anaemia associated with rheumatoid arthritis.

\section{Summary}

Iron deficiency in rheumatoid arthritis was studied by means of marrow iron examinations using the Prussian blue method. The presence of iron in the bone marrow showed that the majority of cases were not iron deficient although the mean cell haemoglobin concentration (M.C.H.C.) was lowered in each case. The reliability of marrow iron examination as a means of detecting iron deficiency in this disease was confirmed by the results of intravenous iron therapy.

In eleven cases, the bone marrow was devoid of stainable iron. With one exception, the anaemia in these patients responded to intravenous iron by a rise in haemoglobin of more than $2 \mathrm{~g}$. per $100 \mathrm{ml}$. In 22 cases, a varying amount of marrow iron was demonstrated. The haemoglobin level rose by more than $2 \mathrm{~g}$. per $100 \mathrm{ml}$. in only one case in this group, and in this patient clinical improvement could not be excluded as the cause of the rise in haemoglobin.

The rise in haemoglobin in iron deficient rheumatoid patients was in general, less than that seen in patients suffering from uncomplicated iron deficiency anaemia. It is suggested that anaemia in some cases of rheumatoid arthritis may be only partially due to iron deficiency. When this iron deficiency is corrected, the residual anaemia, like that in the iron-refractory group, may be due to a toxic factor or factors associated with disease activity.

In many cases there was evidence of a delay in erythroid maturation, in that the number of basophilic normoblasts, expressed as a percentage of total marrow erythroblasts, was increased. This was a feature both of marrows which contained iron and of those which were devoid of iron.

There was a slight increase in marrow plasma cells in ten of the 33 patients examined. In cases in which serum globulin levels were measured, it was observed that marrow plasmacytosis was always associated with a raised serum globulin level, although hyperglobulinaemia was not invariably accompanied by marrow plasmacytosis.

I am indebted to Dr. J. V. Wilson for his help in many ways; to Drs. I. M. P. Dawson and J. J. R. Duthie for criticism and discussion; to Mr. H. Gibson, A.I.M.L.T., for the histological preparations; to the physicians of the Royal Bath Hospital, Harrogate, for allowing me to investigate patients under their charge, and to many members of the nursing and laboratory staffs of the Harrogate Hospitals for co-operation.

\section{REFERENCES}

Alexander, W. R. M., Richmond, J., Roy, L. M. H., and Duthie, J. J. R. (1956). Annals of the Rheumatic Diseases, 15, 12. Beutler, E., Drennan, W., and Block, M. (1954). J. Lab. Clin. Med. 43, 427.

Bunim, J. J. (1954). Annals of the Rheumatic Diseases, 13, 365. Cappell, D. F., Hutchison, H. E., and Smith, G. H. (1947). Brit. med. $J ., 1,403$.

Coleman, D. H., Stevens, A. R., Jr., and Finch, C. A. (1955). Blood, 10, 567.

Dacie, J.' V. (1950a). “Practical Haematology”, p. 80. Churchill, London.

(1950b). Ibid., p. 23.

Dat, and White, J.C. (1949). J. clin. Path., 2, 1.

Dameshek, W. (1950). Blood, 5, 1167.

Dixon, A. St.John, Ramcharan, S., and Ropes, M. W. (1955)

Annals of the Rheumatic Diseases, 14. 51 .

Finch, C. A., Hegsted, M., Kinney, T. D., Thomas, E. D., Rath, C. E. Haskins, D., Finch, S., and Fluharty, R. G. (1950). Blood, $\mathbf{5}, 983$.

Freireich, E. J., Ross, J. F., Bayles, T. B., Emerson, C. P., and Finch, S. C. (1954). Annals of the Rheumatic Diseases, 13,

Gibson, Q. H., and Harrison, D. C. (1945). Biochem. J.. 39, 490

Hammarsten, E., Thorell, B., Åqvist, S.. Eliasson, N., and Åkerman, L. (1953). Exp. Cell Res., 5, 404.

Hayhoe, F. G. J., and Smith, D. R. (1951). J. clin. Path., 4, 47.

Holly, R. G. (1951). Blood, 6. 1159 .

Hutchison, H. E. (1953). Ibid., 8, 236

Heffrey, M. R. (1953a). Ibid., 8, 502

Klein (1953b). Brit. med. J., 2, 912 .

Klein, H., and Block, M. (1953). Blood, 8, 1034

Kuhns, W. J., Gubler, C. J., Cartwright, G. E., and Wintrobe, M. M. (1950). J. clin. Invest., 29, 1505.

Lajtha, L.. G., and Suit, H. D. (1955). Brit. J. Haemat., 1, 55. 
Leitner, S. J., Britton, C. J. C., and Neumark, E. (1949). "Bone Marrow Biopsy", p. 107. Churchill, London.

McCrea, P C. (1957). Lancet, 1, 402.

Mollison, P. L., and Paterson, J. C. S. (1949). J. clin. Path., 2, 109.

Nilsson, F. (1948). Acta med. scand., 130,
Pirrie, R. (1950). Glasg. med. J., 31, 397.

Pratt, P. T., and Johnson, M. E. (1954). Arch. intern. Med., 93, 725

Rath, C. E., and Finch, C. A. (1948). J. Lab. clin. Med., 33, 81.

Richmond, J., Gardner, D. L., Roy, L. M. H., and Duthie, J. J. R (1956). Annals of the Rheumatic Diseases, 15, 217.

Robinson, G. L. (1943). Ibid., 3, 207.

Robs, D. N. (1950). Ibid, 9, 358.

Roy, L. M. H., Alexander, W. R. M., and Duthie, J. J. R. (1955) Ibid., 14, 63.

Sinclair, R. J. G., and Duthie, J. J. R. (1949). Lancet, 2, 646.

- (1950). Brit. med. J., 2, 1257

Stevens, A. R., Jr. (1956) Arch. intern. Med., 98, 550.

Coleman, D. H., and Finch C. A. (1953). Ann. intern. Med. 38, 199 .

Thorell, B. (1947). Acta med. scand., 129, Suppl. 200.

Whitby, L. E. H., and Britton, C. J. C. (1953). "Disorders of the Blood", 7th ed., p. 225. Churchill, London.

Examen du fer de la moelle pour le diagnostic de la déficience en fer dans l'arthrite rhumatismale

\section{RÉSUMF́}

On a étudié la déficience en fer dans l'arthrite rhumatismale par l'examen du fer de la moelle osseuse à l'aide du bleu de Prusse. La présence de fer dans la moelle a montré que dans la majorité des cas il n'existait pas de déficience en fer, bien que la concentration moyenne d'hémoglobine globulaire fût toujours abaissée. .Les résultats de l'administration intraveineuse de fer ont confirmé la sûreté de l'examen du fer médullaire comme moyen de mettre en évidence la déficience en fer dans l'arthrite rhumatismale.

Dans onze cas, la moelle osseuse était dépourvue de fer colorable. A une exception près, l'anémie chez ces malades a réagi à l'administration de fer par voie intraveineuse par une augmentation de l'hémoglobine au dessus de 2 grammes par $100 \mathrm{cc}$. Dans 22 cas on a mis en évidence la présence d'une quantité variable de fer dans la moelle. Le taux d'hémoglobine s'est élevé au dessus de 2 g. par $100 \mathrm{cc}$. dans un seul de ces cas et cette augmentation aurait pu être due à l'amélioration clinique.

L'augmentation d'hémoglobine chez les rhumatisants déficients en fer était en général moindre que celle observée chez des malades souffrants d'anémie hypochrome simple. Il est suggéré que dans certains cas d'arthrite rhumatismale l'anémie puisse n'être que partiellement due à une déficience en fer. Quand cette déficience en fer est corrigée, l'anémie résiduelle, comme celle du groupe réfractaire au fer, peut être due à un ou plusieurs facteurs toxiques associés à l'activité morbide.

Dans plusieurs cas il y avait des signes d'un delai dans la maturation érythroide, en ce sens que le nombre de normoblastes basophiles, exprimé en pourcentage du total d'érythroblastes médullaires, était augmenté. Ceci constituait un trait à la fois des moelles qui contenaient du fer et de celles qui en étaient dépourvues.
On a trouvé une légère augmentation des plasmocytes médullaires chez 10 des 33 malades examinés. Quand on déterminait le taux de globuline sérique, on observait que la plasmocytose médullaire était toujours associée à une augmentation du taux de globuline sérique, bien que l'hyperglobulinémie ne fût pas invariablement accompagnée par de la plasmocytose médullaire.

Examen del hierro medular en el diagnóstico de la carencia férrica en la artritis reumatoide

\section{Sumario}

Se estudió la deficiencia férrica en la artritis reumatoide por el examen del hierro en la médula ósea por el método de azúl de Prusia. La presencia de hierro en la médula ósea mostró que en la mayoría de los casos no hubo deficiencia férrica, aunque la concentración media de hemoglobina globular fuese siempre disminuida. Los resultados de administración endovenosa de hierro confirmaron la exactitud del examen del hierro medular como medio de evidenciar la deficiencia férrica en la artritis reumatoide.

En once casos hierro colorable no fué encontrado en la médula ósea. Con una excepción. la anemia en estos enfermos respondió a la medicación férrica endovenosa por un ascenso de la hemoglobina a más de dos gramos por $100 \mathrm{cc}$. En 22 casos se evidenciaron cantidades variables de hierro en la médula. En un solo de estos casos la cifra de hemoglobina rebasó el 2 gramos por $100 \mathrm{cc}$. y hasta en este caso el aumento podría atribuirse a una mejoría clínica.

El aumento de hemoglobina en los reumáticos co@̊ deficiencia férrica fué generalmente menor que observado en enfermos con anemia ferripriva simple Se sugiere que en ciertos casos de artritis reumatoide anemia se debería tan solo en parte a una deficienciáa férrica. Al corregir esta deficiencia, la anemia residual, como en el grupo refractario al hierro podría deberse a uno o más factores tóxicos asociados a la actividad mórbida.

En varios casos se vieron signos de demora en la maduración eritroide, en el sentido de que la cifra de normoblastos basófilos expresada en el porcentaje del total de eritroblastos medulares, fué aumentada. Esto constituyó un rasgo característico tanto de las médulas que contuvieron hierro como de las que fueron desprovistas de él.

En 10 de los 33 enfermos investigados encontrose una ligera aumentación en la cifra de los plasmocitos medulares. Al determinar las cifras de globulina sérica se observó que la plasmocitosis medular fué siempre asociada a un aumento de éstas, aunque una hiperglobulinemia no se vió neceseriamente acompañada de plasmocitosis medular. 